\title{
Anovel Immunological Technique for Identification of Human Seminal Fluid
}

\author{
Foud H. Kamel*
}

Date of acceptance 6/1/2009

\begin{abstract}
:
An immunological technique was investigated for the detection of human semen in forensic analysis. This technique included a preparation of anti-human seminal plasma antibodies, by immunizing rabbits with treated human semen. The human semen was treated with an acid to prevent cross reactivity with other human body fluids. The antibody produced was tested against different animal's seminal fluid samples (dog, goat ,sheep, cow) and human body fluids( saliva, blood, vaginal fluid, ear wax and human semen). It was found that using this developed technique was only selectively responsed with human semen .

The prepered kit was evaluated and tested in Forensic laboratory- Ministry of Health. Finally, results were obtained in a comparison with the recommended techniques.
\end{abstract}

Key words: forensic science, identification, immunoassay seminal vesicle specific antigen, semen, seminal vesicles

\section{Introduction :}

Over the years, laboratories of forensic medicine have developed different techniques to detect semin in vaginal swabs, especially in cases of azoospermia and aspermia. Sperms are produced within tubules in the testes that are called the seminiferous tubules. Lining these tubules are layers of nursing cells called Sertoli cells which pass nutrients back and forth from the blood supply and the developing sperm cells [1]. The female reproductive tract is intermittently exposed to immunologically foreign cells and materials as a result of sexual intercourse. These cells are predominantly spermatozoa, which are suspended in acomplex specialized fluid that is seminal plasma. Most mammalian spermatozoa and the seminal plasma possess sperm specific antigens , alloantigens and blood group antigens[2], making them a potential source for immunologically mediated reactions. Human semen, in the staining method or in vaginal swabs are routinely identified. On this basis it is difficult to be determined where there are few or no spermatozoa, or where the material has been deteriorated [3].

Other workers $[4,5,6,7]$ attempted to identify human semen on the basis of chemical or biochemical methods (e.g., choline and acid phosphatase), which gives a high probability for detection of human semen . However, it was suggested felt that an immunological test would provide additional evidence for the presence of semen. In 1963, Coombs et.al. [8] described the methodology of such a technique but no vaginal samples were used. Moreover, its specificity was debatable and no assessment of sensitivity was made .Few authors $[9,10]$ described other methods using anti-serum, but no vaginal samples were tested and the specificity for semen was not demonstrated . Keil-W.et.al 1996 [11]obtained positive results using a

\footnotetext{
* Erbil Medical Technical Institute, Iraq.
} 
complement-fixation test for human semen in the vagina after intercourse but no tests against other human fluids were performed .This method may be specific but the authors noted cross reactions with semen-free vaginal swabs which were subsequently diluted out.However ,as the complementfixation test is quantitative ,this approach may be more sound than a qualitative precipitin test. Baxter,1973 [12] described that Electroimmunodiffusion of semen samples and other antigens(qualitative test) for human semen will give equivocal results ,that's because the semen phosphatase has an $\alpha 1$ and $\alpha 2$ mobility ,while the vaginal enzyme has mobility equivalent to a slow $\beta-\gamma$ globulin.

Allen,1995 [13] explained an enzyme linked immunosorbent assay for detection of seminal fluid using a monoclonal antibody to prostatic acid phosphatase . His results revealed no cross reactivates with human vaginal fluid ,blood, saliva ,female urine ,nasal discharge and earwax or face's.

Keil et.al. ,1996 [11] employed an MHS-5-ELISA(SEMA kit)as a useful tool for medico-forensic semen detection in vaginal swabs, probably even in cases of azoospermic or aspermia. So an immunological method would be advantageous and providing its specificity and sensitivity to detect traces of human semen in vaginal swab [12].

From this point of view, our artical deals with the problems encountered in immunological technique for identification of human sminal fluid and the production of diagnostic kit .

\section{Materials and methods:}

Human semen fluid was collected( M.O.S.T.-Dep.of health and AL-Samarie hospital) directly in to sterile container and incubated at $37^{\circ} \mathrm{C}$ for 30 minutes to liquefied, and then centrifuged at $3000 \mathrm{rpm}$ for 15 minutes to separate seminal plasma from the spermatozoa.

Seminal plasma treated with acidic reagent ,by adding $100 \mu$ of acidic reagent to one milliliter of seminal plasma sample and centrifuged at 3000 rpm for about 15 minutes to obtain sample free of acid phosphatase, this was investigated by paper electrophoresis[14] in comparism with standard acid phosphatase and hole semen plasma.

Rabbits were injected intramusculary with treated and other group with untreated seminal plasma in Freunds complete adjuvant in order to produce antibodies. Similar injections were performed with seminal plasma but in Freunds incomplete adjuvant [15]. Then the immunized rabbites were bleed out to obtain serum( anti-treated and untreated seminal plasma). In addition, a precipitate test line obtained by precipitation reaction of seminal fluid against a commercial anti-serum ( as antigen).

Varios samples of antibodies, human body fluid and animals semen (forensic medicine laboratory -M.O.H.) samples were diluted with normal saline and tested together in different dilution using precipitation test (Ring test)[16] .

\section{Results and discussion:}

Rresults of paper electrophoresis for treated semen fluid samples in a comparison with standared acid phosphatase and hole semen plasma, suggested that they are free of acid phosphatase .This results indicate to the efficiency of this technique to get rid of cross reactivity with other body fluids.

In human, anti-sperm antibodies can not be distinguished from anti- seminal 
plasma antibody. This suggests that the major antigens of ejaculated human sperm might be derived from seminal plasma, which contains numerous potentially immunogenic proteins and enzymes .So far,at least 16 antigens have been identified in semen, and 7 of these are attributed to sperm it self[18] That is why we immunized rabbits with seminal plasma.

Precipitation test ( ring test) is very sensitive for detecting antigen or antibody and to apply this test antigen and antibody should be soluble forms [16]. Precipitation test have been used for evaluation our produced antiplasma semen .So, these anti-semen samples were tested with undiluted semen samples(dog, goat ,sheep, cow and human).As aresults of this test adistinct precipitation ring was formed only with human semen table(1).

Table(1)Represents the results of ring test of diluted anti-untreated human semen samples against human $\&$ animals semen samples.

\begin{tabular}{|c|c|c|c|c|c|}
\hline $\begin{array}{c}\text { Anti-untreated } \\
\text { human semen } \\
\text { (Diluted). }\end{array}$ & $\begin{array}{c}\text { Diluted } 1 / 2 \\
\text { Human semen }\end{array}$ & $\begin{array}{c}\text { Diluted } 1 / 2 \text { Goat } \\
\text { semen }\end{array}$ & $\begin{array}{c}\text { Diluted } 1 / 2 \\
\text { Sheep semen }\end{array}$ & $\begin{array}{c}\text { Diluted } 1 / 2 \\
\text { Dog } \\
\text { semen }\end{array}$ & $\begin{array}{c}\text { Diluted } 1 / 2 \text { Cow } \\
\text { semen }\end{array}$ \\
\hline Net & positive & Negative & Negative & Negative & Negative \\
\hline $1: 2$ & positive & Negative & Negative & Negative & Negative \\
\hline $1: 4$ & positive & Negative & Negative & Negative & Negative \\
\hline $1: 8$ & positive & Negative & Negative & Negative & Negative \\
\hline
\end{tabular}

Table(2) shows the results of ring test of undiluted anti-untreated semen samples against diluted samples( human plasma, saliva, serum and vaginal fluid). As aresult of this test, very faint precipitation lines (weak positive)were produce with plasma, human serum and saliva. Vaginal fluid sample gave strong reactions (strong positive) in dilution $(1 / 10,1 / 100)$, while it was sluggish positive in dilution $(1 / 1000,1 / 2000)$ but negative in dilution (1/8000 and1/10 000$)$. So, it may possible to demonstrate the complete identity of one antigen present in saliva and semen, and at least two antigens in semen free vaginal fluid samples, which were immunologically identical with antigens in semen. The results obtained above clearly demonstrated that the anti-serum of untreated semen was species specific, but cross reactions with other human body fluids. However, as both male and female genital organs arise from a common embryological origin.It is likely that female and male genital secretions contain acid phosphatase. This has recently been demonstrated [18]. Prevous immunological factors considered an important tools in choosing a suitable technique for the detection of human semins.

Table(2) Represents the results of ring test of undiluted anti-untreated semin sample against different dilution human samples( vaginal fluid, saliva,human serum and human plasma).

\begin{tabular}{|c|c|c|c|c|c|}
\hline $\begin{array}{c}\text { Dilution human } \\
\text { samples }\end{array}$ & Human semen & Vaginal fluid & Saliva & Human serum & Human plasma \\
\hline $1: 10$ & Strong positive & Strong positive & Weak positive & Weak positive & Weak positive \\
\hline $1: 100$ & Strong positive & Strong positive & Negative & Negative & Negative \\
\hline $1: 1000$ & Strong positive & Sluggish positive & Negative & Negative & Negative \\
\hline $1: 2000$ & Strong positive & Sluggish positive & Negative & Negative & Negative \\
\hline $1: 4000$ & Strong positive & Weak positive & Negative & Negative & Negative \\
\hline $1: 8000$ & Sluggish positive & Negative & Negative & Negative & Negative \\
\hline $1: 10000$ & Weak positive & Negative & Negative & Negative & Negative \\
\hline
\end{tabular}


Table (3) presented similar results of human semen as in table [1], while other treated body fluids were reflected to negative results. This developed technique for detection of human semen has several advantages for routine forensic work, no positive reactions have been observed with any material other than human semen. This developed immunological technique need a simple equipments and reagents and characterized as a novel immunological technique of a high sensitivity and specificity in very short time(about 2 minutes).

Table (3) Represents the results of ring test of undiluted anti-treated semin sample against different dilution human samples( vaginal fluid, saiva,human serum and human plasma).

\begin{tabular}{|c|c|c|c|c|c|}
\hline $\begin{array}{c}\text { Dilution } \\
\text { human } \\
\text { samples }\end{array}$ & $\begin{array}{c}\text { Human } \\
\text { semen }\end{array}$ & $\begin{array}{c}\text { Vaginal } \\
\text { fluid }\end{array}$ & Saliva & $\begin{array}{c}\text { Human } \\
\text { serum }\end{array}$ & $\begin{array}{c}\text { Human } \\
\text { plasma }\end{array}$ \\
\hline $1: 10$ & $\begin{array}{c}\text { Strong } \\
\text { positive }\end{array}$ & Negative & Negative & Negative & Negative \\
\hline $1: 100$ & $\begin{array}{c}\text { Strong } \\
\text { positive }\end{array}$ & Negative & Negative & Negative & Negative \\
\hline $1: 1000$ & $\begin{array}{c}\text { Strong } \\
\text { positive }\end{array}$ & Negative & Negative & Negative & Negative \\
\hline $1: 2000$ & $\begin{array}{c}\text { Strong } \\
\text { positive }\end{array}$ & Negative & Negative & Negative & Negative \\
\hline $1: 4000$ & $\begin{array}{c}\text { Strong } \\
\text { positive }\end{array}$ & Negative & Negative & Negative & Negative \\
\hline $1: 8000$ & $\begin{array}{c}\text { weak } \\
\text { positive }\end{array}$ & Negative & Negative & Negative & Negative \\
\hline $1: 10000$ & Negative & Negative & Negative & Negative & Negative \\
\hline
\end{tabular}

As a results of a novel immunological technique a new immunological kit was developed. The kit contains positive control (human semen), negative control, reagent, anti-semen fluid and buffer.

\section{Reference:}

1. Guyton,A.C. 1991. Text book of medicalhysiology. $8^{\text {th }}$ edi,W.S.Saude rs com., 885-897.

2. Seely,R.R.,Stephens,T.D.,philipTat e,D.A. 1996. Essentials of Anatomy physiology $2^{\text {nd }}$.Edi. the Mc Graw-Hill companies,Inc. 515525.
3. Pawlowski R. and Brinkmann B. 1992. Evaluation of sperm specific lactate dehydrogenase isoenzyme C4; application to semen detection in stains. Int J. Legal Med.105(2): 133-126.

4. Pereira, Margaret \& Martin, P.D. 1976. Problems Involved in the Grouping of Saliva, Semen and Other Body Fluids. Journal of the Forensic Science Society.16:151

5. Sivaram and Bami ,H.L. 1971. Identification of seminal stains by the inhabition, J.forens.Sci. Soc., 11 $: 187$.

6. Satcher,D, Hughes, J.M. 1993. Laboratory methods for Diagnosis. DC.USA.

7. Sato I, Kojima K, Yamasaki $\mathrm{T}$, Yoshida K, Yoshiike M, Takano S, Mukai T, Iwamoto T. 2004. Rapid detection of semenogelin by onestep immunochromatographic assay for semen identification. J Immunol Methods. 287(1-2): 13745 .

8. Coombs,R.R.A.,Richards,C.B. and Dodd, B.Culliford ,B.J. 1964.Titration of antisera to soluble proteins on basis of agglutnation reaction. Nature ,Lond. $201: 1092$.

9. Leithoff and Leithoff 1965 .Immunoelectrophoretic examinations of human semin. Acta med.leg.Soc. 18:55-71.

10. S.J.Baxter 1973. Immunological identification of human semen .Medicine, Science and the law.13 ( 3 ).

11. Keil-W.et.al 1996. MHS-5 in detecting seminal fluid in vaginal swabs.Int-J-Legal-

Med.108(4):186-90.

12. Chen, Jt and Hortin, GL 2000. Interferences with semen detection by an immunoassay for a seminal vesicle-specific antigen. J.forens. Sci. Soc.45(12): 263. 
13. Allen-SM 1995. An enzyme linked immunosorbent assay for detecion of seminal fluid using a monoclonal antibody to prostatic acid phosphatase .J-Immunoassay. 16(3):297-308.

14. Nowotny A. 1979. Basic exercises in immunolochemistry. Labratory manual. p.23.

15. Rodgers R. P.C. 1995. Clinical Laboratory Methods for detection of antigens and antibodies. Stites D. P.; Stobo J. D; Fundberg H. H.
\& wells J. V. "Basic and clinical Immunology" $10^{\text {th }}$ Ed. Lange Medical Publication. 151-193.

16. Prof.C.R.Maiti 1997. Aconcise note on Medical Laboratory technology. 106.

17. Fundberg H.H. 1980. Basic and clinical immunology.Chapter 13:168.

18. Willott , G.M. 1972 .Forensic Science Abstracts. J.forens.Sci. Soc.12: 263.

\section{استحداث طريقة مناعية جديده لتشخيص السائل المــوي البشري}

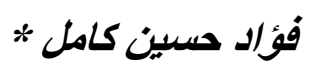

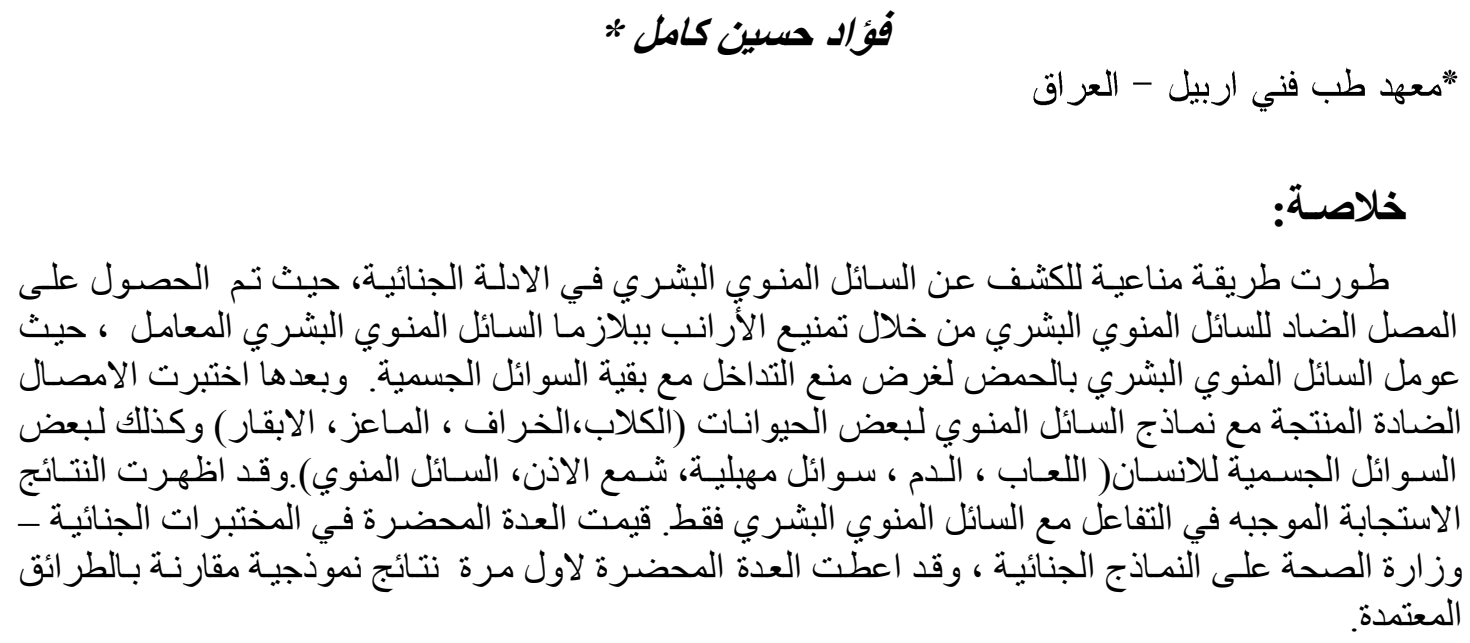

